\title{
Pengaruh Partisipasi Masyarakat Terhadap Realisasi Anggaran Program Inovasi Pembangunan dan Pemberdayaan Kewilayahan Kota Bandung
}

\author{
${ }^{1}$ Suhari Ramdani, ${ }^{2}$ Mubarok \\ ${ }^{1}$ UIN Sunan Gunung Djati Bandung, Indonesia; Suhariramdani68@gmail.com \\ ${ }^{2}$ UIN Sunan Gunung Djati Bandung, Indonesia; Mubarok.crd@gmail.com
}

\begin{abstract}
This journal discusses the influence of public participation on the realization of the budget of the Development Innovation Program and the Empowerment of the Area in the District of Bojongloa Kidul, Bandung. This research is important to do because the percentage of budget realization of PIPPK in Bojongloa Kidul sub-district is very high in the last four years where the high budget realization of the program must be in line with the participation of the people in the region. The theory used in this research is the theory of community participation from Cohen\&Uphoff (1980) which discusses funding for community participation in planning, implementation, utilization, and evaluation and budget realization theory from Indra Bastian, which discusses optimal budget realization (2010). The research method in this research is a quantitative associative research method which means that this study is intended to find out the clear relationship between Community Participation and Realization of PIPPK Budget with data and analysis that uses a lot of numbers. The results of this study indicate that the influence exerted by Community Participation on the realization of the PIPPK budget is $0.856(85.6 \%)$ and falls under the very high influence criteria. Thus it can be concluded that there is a very high influence of Community Participation on the realization of the PIPPK budget in Bojongloa Kidul District, Bandung City. This shows that community participation has an important role in the success of the Regional Development and Empowerment Innovation Program in the District of Bojongloa Kidul, Bandung.
\end{abstract}

Keywords: Policy Innovation, Civil Community, Participation, Empowerment, Budget Realization

\section{Pendahuluan}

Pelaksanaan anggaran dalam suatu program pemerintah merupakan hal yang menarik untuk diamati terlebih jika program tersebut merupakan program yang berkaitan langsung dengan masyarakat. Salah satu program yang berkaitan langsung dengan masyarakat yaitu Program Inovasi Pembangunan dan Pemberdayaan Kewilayahan (PIPPK) yang dicanangkan oleh Pemerintah Kota Bandung. Program ini merupakan program yang lahir dari adanya pandangan serta pemikiran bahwa perubahan yang dinamis dari kondisi masyarakat dapat dicapai dengan peran serta dari masyarakat luas mulai dari tingkat paling bawah dan melalui metode pemberdayaan masyarakat. Ini menunjukkan bahwa program ini merupakan satu jalan bagi masyarakat untuk turut serta berperan aktif dalam upaya memaksimalkan potensi yang ada di wilayahnya. Dengan adanya partisipasi dan peran aktif dari masyarakat diharapkan program yang dilaksanakan dan anggaran yang digunakan dapat sesuai dengan apa yang menjadi kebutuhan masyarakat tersebut. Hadirnya PIPPK merupakan suatu sarana bagi masyarakat untuk turut andil dalam pembangunan dan pemberdayaan di wilayahnya.

Partisipasi merupakan suatu tindakan dari seseorang dalam mengambil peran atau bagian dari sebuah kegiatan dengan tujuan untuk memperoleh manfaat dari kegiatan tersebut. Tindakan tersebut merupakan akibat dari adanya proses interaksi sosial yang terjadi antara individu tersebut dengan masyarakat yang lain (Andriani, et al, 2018). Di dalam kegiatan pembangunan, partisipasi masyarakat merupakan bentuk kepedulian dan kesadaran dari masyarakat serta tanggungjawab terhadap pembangunan yang sedang berlangsung yang merupakan salah satu perwujudan dari upaya perbaikan kualitas hidup masyarakat. Dengan 
adanya partisipasi ini, artinya masyarakat menyadari bahwa dalam sebuah pembangunan yang bertujuan untuk memperbaiki kualitas hidup mereka ini bukanlah sekedar tanggungjawab dari aparat pemerintah saja melainkan juga merupakan tuntutan bagi masyarakat itu sendiri yang ingin diperbaiki kualitas hidupnya.

Partisipasi masyarakat dapat juga diartikan sebagai komunikasi antara pemerintah dengan masyarakat dimana pemerintah ialah sebagai pembuat atau pemegang kebijakan sedangkan masyarakat ialah sebagai objek yang secara langsung terdampak dari kebijakan tersebut. Masyarakat dapat mendukung dan memberi masukan atau pendapatnya terhadap program kebijakan yang ditetapkan oleh pemerintah tersebut dengan cara memberikan respon positif, namun masyarakat juga dapat menolak kebijakan yang ditetapkan oleh pemerintah tersebut (Agustin, 2015). Selanjutnya, bentuk partisipasi masyarakat yang lebih aplikatif dikemukakan oleh Cohen dan Uphoff (1980). Bentuk partisipasi tersebut diantaranya yaitu:

1. Participation in decision making

Merupakan partisipasi atau keikutsertan masyarakat pada masa perencanaan dari suatu pembangunan dimana pada masa ini kebijakan pembangunan dirumuskan dan ditetapkan. Artinya masyarakat bisa memberikan saran dan pendapat mereka tentang bagaimana dan seperti apa pembangunan akan dilaksanakan. Keterlibatan dari masyarakat dalam proses ini dapat dilihat dari keikutsertaan masyarakat dalam menghadiri musyawarah (musrenbang), mengemukakan pendapat saat pertemuan atau rapat, dan memberikan informasi dan data dalam setiap pertemuan.

2. Participation in implementation

Merupakan bentuk tindakan ambil bagian atau kontribusi dari masyarakat atas dilaksanakannya pembangunan. Bentuk kontribusi dari masyarakat ini dilakukan untuk menunjang terlaksananya pembangunan. Seperti yang dikemukakan oleh Cohen dan Upphoff bahwa kontribusi yang dapat diberikan oleh masyarakat pada tahap implementasi ini ialah dapat melakukan kontribusi dengan uang, tenaga ataupun materi.

3. Participation in benefit

Merupakan peran dari masyarakat dalam hal memanfaatkan hasil dari pembangunan yang telah dilaksanakan sebelumnya dimana pembangunan yang dilaksanakan bisa dirasakan manfaatnya oleh masyarakat.

4. Participation in evaluation

Merupakan keikutsertaan masyarakat untuk menilai dan mengkritisi hasil dari pembangunan yang telah dilaksanakan. Pada tahap ini juga masyarakat berhak untuk memberikan saran dan masukan terhadap proses pelaksanaan pembangunan yang telah dilaksanakan guna menjadi pembelajaran bagi pembangunan yang akan dilaksanakan selanjutnya. Pada tahap inilah masyarakat menggunakan haknya sebagai evaluator dalam pembangunan.

Pada pelaksanaannya, PIPPK melibatkan empat lembaga kemasyarakatan yaitu Rukun Warga, Lembaga Pemberdayaan Masyarakat, Pemberdayaan Kesejahteraan Keluarga, dan Karang Taruna. Anggaran yang diberikan bagi setiap lembaga tersebut berjumlah Rp. 100.000.000 (seratus juta rupiah) dalam satu periode anggaran yaitu satu tahun. Salah satu indikator untuk menilai kinerja dari program tersebut bisa dilakukan dengan melihat persentase realisasi anggaran dari program tersebut. Di Kecamatan Bojongloa Kidul sendiri persentase dari realisasi anggaran PIPPK dari tahun 2015 sampai tahun 2018 disajikan dalam tabel berikut: 
Tabel 1

Realisasi Anggaran PIPPK Periode 2015-2018

\begin{tabular}{cccc}
\hline Tahun & Anggaran & Realisasi & Persentase \\
\hline 2015 & $4,997,800,000$ & $4,952,919,031$ & $99 \%$ \\
2016 & $6,999,910,000$ & $6,959,157,407$ & $99 \%$ \\
2017 & $6,180,792,821$ & $6,105,275,547$ & $99 \%$ \\
2018 & $4,421,698,942$ & $4,250,627,515$ & $96 \%$ \\
\hline
\end{tabular}

Gambar 1

Grafik Realisasi Anggaran PIPPK

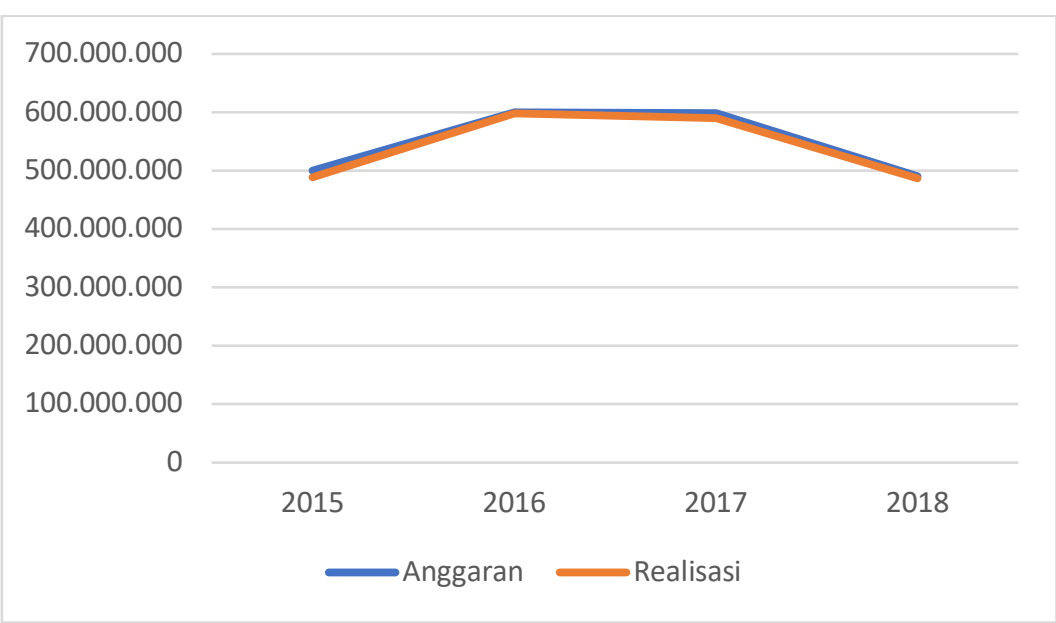

Sumber: Grafik diolah Peneliti, 2020

Dari hasil tersebut diketahui realisasi anggaran PIPPK dari tiap Lembaga Kemasyarakatan yang ada di lingkungan wilayah Kecamatan Bojongloa Kidul dari tahun 2015 sampai dengan tahun 2018 berada diatas 90\%. Ini menunjukkan bahwa tingkat realisasi anggaran pada PIPPK di Kecamatan Bojongloa Kidul sudah baik.

Anggaran ialah ukuran finansial yang di dalamnya berisi pernyataan tentang estimasi kinerja yang ditargetkan dapat diselesaikan dalam satu periode tertentu (Mardiasmo, 2009). Pada umunya realisasi anggaran yang dimaksud ialah suatu pencapaian dari anggaran yang telah diestimasikan sebelumnya dalam satu periode tertentu (Halim, 2017). Adapun pengertian menurut Tanjung realisasi anggaran merupakan besaran anggaran yang terserap dalam kegiatan keuangan pemerintah pusat atau daerah yang dibandingkan dengan anggaran yang telah ditetapkan dalam periode tertentu (Tanjung, 2015). Realisasi anggaran dapat dilihat dari besarnya anggaran pada tahun berjalan. Realisasi anggaran merupakan komitmen pemerintah yang mengacu pada pertumbuhan ekonomi lebih tinggi sehingga mampu mensejahterakan masyarakat. Rendahnya serapan belanja pemerintah akan menekan pertumbuhan ekonomi bila kemampuan pengeluaran pemerintah lebih buruk dibandingkan tahun lalu, dan resiko pada pertumbuhan ekonomi yang tidak maksimal. Realisasi anggaran merupakan suatu rangkaian sistem atau siklus yang didalamnya terdiri dari kegiatan persiapan, proses pelaksanaan, dan 
penyelesaian. Sejalan dengan siklus tersebut, (Bastian, 2010) mengemukakan teori mengenai tiga kegiatan utama dalam realisasi anggaran. Kegiatan tersebut diantaranya yaitu:

\section{Pencairan Anggaran}

Pencairan anggaran ialah suatu tahap yang didalamnya merupakan kegiatan belanja baik itu belanja barang, belanja jasa ataupun belanja modal dan aktivitas jasa sebagai bentuk proses pembuatan anggaran kas sesuai dengan prosedur yang berlaku. Kegiatan ini dimulai dengan tahap persiapan yang terdiri dari kegiatan pembuatan prosedur dan formulir serta pembuatananggaran kas; tahap proses pelaksanaan terdiri dari kegiatan pengumpulan bukti untuk pencatataan, penyelesaian tata prosedur pencatatan barang dan modal, serta pelaporanaktivitas jasa

2. Realisasi Pendapatan

Realisasi pendapatan, yaitu sebuah tahapan yang dimulai dengan tahap persiapan berupa penghitungan potensi lalu membuat regulasi mengenai prosedur serta pembuatan formulir. Kegiatan ini dimulai dengan tahapan persiapan yang terdiri dari kegiatan menghitung potensi dan membuat regulasi untuk prosedur serta formulir; tahap proses pelaksanaan terdiri dari kegitan penagihan dan pengumpulan pendapatan serta pengenaan sanksi dan insentif.

3. Pelaksanaan Program

Merupakan suatu tahap pelaksanaan yang terdiri dari kegiatan penagihan dan pengumpulan pendapatan serta pengenaan sangsi dan insentif. Kegiatan ini dimulai dengan tahapan persiapanyang terdiri dari kegiatan pembentukkan tim dam meembuat data aturan serta pembagianbeban kerja. Tahap proses pelaksanaaan terdiri dari kegiatan pelaksanaan pekerjaan, sementara tahap penyelesaian terdiri dari kegiatan finalisasi produk dan pembuatan laporan.

Penelitian ini bertujuan untuk analisis pengaruh partisipasi masyarakat terhadap realisasi anggaran PIPPK di Kecamatan Bojongloa Kidul Kota Bandung. Persentase realisasi anggaran dari setiap lembaga kemasyarakatan yang ada dilingkungan wilayah Kecamatan Bojongloa Kidul yang tinggi dinilai telah mampu melaksanakan program dengan baik, namun belum tentu dalam prosesnya melibatkan partisipasi dan peran aktif dari masyarakat seperti yang diamanatkan dalam peraturannya.

\section{Metode Penelitian}

Penelitian yang dilakukan penulis ini bertujuan untuk mengetahui hubungan dari partisipasi masyarakat terhadap realisasi anggaran Program Inovasi Pembangunan dan Pemberdayaan Kewilayahan (PIPPK) di Kecamatan Bojongloa Kidul Kota Bandung, sehingga peneliti mengkategorikan penelitian ini sebagai penelitian asosiatif. Sedangkan berdasarkan kepada jenis dan analisis data yang digunakan peneliti dalam penelitian ini, maka penelitian ini merupakan bentuk penelitian kuantitatif. Populasi dalam penelitian ini adalah masyarakat Kecamatan Bojongloa Kidul yang berjumlah 76.808 orang. sampel yang diambil sebanyak 398 orang. jumlah ini ditentukan menggunakan teori dari Yamane dengan rumus $n=\frac{\mathrm{N}}{\mathrm{N} \cdot d^{2}+1}$.

Sumber data penelitian ini didapat dari sumber primer dan sekunder. Sumber primer dari penelitian ini didapat langsung di lokasi penelitian dengan cara survey melalui kuesioner. Sedangkan sumber data sekunder didapat dari berbagai literatur dan media seperti media cetak 
maupun elektronik termasuk dari internet. Teknik pengolahan analisis data yang digunakan dalam penelitian ini yaitu

1. Menentukan rentang dan kategori penilaian

Teknik ini digunakan dengan cara menjabarkan variabel menjadi beberapa indikator yang nantinya indikator tersebut menjadi tolak ukur disusunnya beberapa item pernyataan atau pertanyaan dari angket/kuesioner yang disusun peneliti yang nantinya akan dijawab oleh responden. Setiap pertanyaan atau pernyataan dalam kuesioner dibagi dalam 5 alternatif jawaban yang disusun bertingkat dengan pemberian bobot nilai (skor) kemudian Skor total masing-masing indikator yang didapat dari jawaban responden tersebut kemudian dikategorikan dengan cara pentabulasian data. Hal tersebut dilakukan dengan cara menentukan nilai indeks maksimum dan minimum serta interval dan jaraknya dengan cara sebagai berikut:

a. Nilai indeks minimum $=$ (skor minimum) $x($ jumlah pertanyaan $) \times(j u m l a h$ responden)

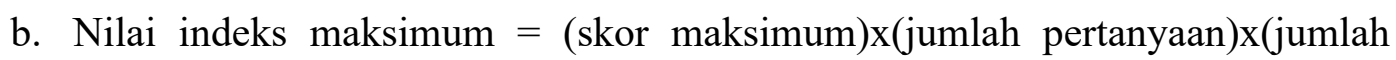
responden)

c. $\quad$ Interval $=($ nilai indeks maksimum $)-($ nilai indeks minimum $)$

d. Jarak interval $=$ Interval

Jumlah Jenjang

Untuk menentukan kategorinya dapat dilihat pada gambar garis kontinum berikut:

Skor Minimum

Skor Maksimum

\begin{tabular}{|l|l|l|l|l|} 
SR & $\mathrm{R}$ & $\mathrm{S}$ & $\mathrm{T}$ & $\mathrm{ST}$ \\
\hline & & & &
\end{tabular}

Sangat Rendah (SR), Rendah (R), Sedang (S), Tinggi (T), Sangat Tinggi (ST)

2. Uji hipotesis ( Uji t dan Uji F)

Uji t merupakan teknik pengujian untuk mengetahui pengaruh masing-masing variabel independen terhadap variabel dependennya. Pada penelitian ini, uji-t digunakan untuk menguji apakah pertanyaan hipotesis benar atau tidak. Uji ini digunakan untuk mengetahui apakah dalam model regresi variabel independen partisipasi masyarakat $(\mathrm{X})$, perencanaan (X1), pelaksanaan (X2), pemanfaatan (X3), dan evaluasi (X4) secara parsial berpengaruh signifikan terhadap realisasi anggaran (Y). Uji t dilakukan dengan menggunakan rumus sebagai berikut:

$$
t=\frac{\sqrt{N-2}}{\sqrt{1-r^{2}}}
$$

Keterangan:

$\mathrm{N}=$ Jumlah responden ujicoba

$\mathrm{r}=$ Koefisien korelasi

Uji F digunakan untuk menguji tingkat signifikansi koefisien regresi variabel independen secara simultan terhadap variabel dependen. Maka dari itu, uji F ini digunakan oleh peneliti untuk mengetahui apakah variabel independen partisipasi masyarakat (X), perencanaan (X1), pelaksanaan (X2), pemanfaatan (X3), dan 
evaluasi (X4) berpengaruh signifikan secara bersama-sama terhadap variabel dependen realisasi anggaran (Y). Rumus untuk uji f adalah sebagai berikut:

$$
F_{h}=\frac{R^{2} / k}{\left(1-R^{2}\right) /(n-k-1)}
$$

Keterangan:

$\mathrm{R}=$ Koefisien korelasi ganda

$\mathrm{k}=\mathrm{Jumlah}$ variabel independen

$\mathrm{n}$ = Jumlah anggota sampel

3. Analisis koefisien determinasi

Koefisien determinasi digunakan untuk menunjukkan seberapa besaran pengaruh partisipasi masyarakat terhadap realisasi anggaran pada PIPPK di Kecamatan Bojongloa Kidul Kota Bandung. Untuk mengukur koefisien determinasi ini penulis menggunakan rumus Supranto dalam (Sugiyono, 2016) yaitu sebagai berikut:

Keterangan:

$$
\mathrm{Kd}=\mathrm{r}^{2} .100 \%
$$

$\mathrm{Kd} \quad=$ Koefisien determinasi

$\mathrm{r} \quad=$ Koefisien korelasi

Koefisien determinasi digunakan penulis untuk mendapatkan unsur ketelitian dan kemudahan.

\section{Hasil dan Pembahasan}

Penelitian ini diawali dengan mengumpulkan data realisasi anggaran PIPPK beserta profil dan tipologi dari Kecamatan Bojongloa Kidul. Dari data tersebut didapat jumlah populasi yang akan diteliti. Hasilnya ditentukan sampel sebanyak 398 orang dari populasi sebesar 76.808 orang. Instrument penelitian yang digunakan yaitu kuesioner yang didalamnya berisi pernyataan-pernyataan yang masing-masing dari pernyataan tersebut memiliki lima kemungkinan jawaban yang dipilih dan dianggap oleh responden sesuai dengan pendapatnya. Kemudian ditentukan rentang nilai dari jawaban yang didapat dari responden. Hasilnya, jumlah skor keseluruhan dari beberapa dimensi yang ada pada variabel partisipasi masyarakat mempunyai nilai sebesar 13.288 yang terletak antara rentang 12.178,8 dan 15.044,4 dengan demikian termasuk pada interval yang berkategori tinggi. Hal ini menunjukkan adanya partisipasi masyarakat dalam Program Inovasi Pembangunan dan Pemberdayaan Kewilayahan (PIPPK).

Setelah dilakukan transformasi skala pengukuran data selanjutnya dihitung data input dalam perhitungan analisis regresi. Data input dalam perhitungan analisis regresi diperoleh dari skor total perencanaan (X1), pelaksanaan (X2), dan pemanfaatan (X3) dan evaluasi (Y). Koefisien regresi unuk model yang diteliti berdasarkan hasil perhitungan dapat dilihat pada tabel berikut ini: 
Tabel 2

\section{Koefisien Regresi dan Uji Signifikansi}

\section{Coefficients $^{\mathrm{a}}$}

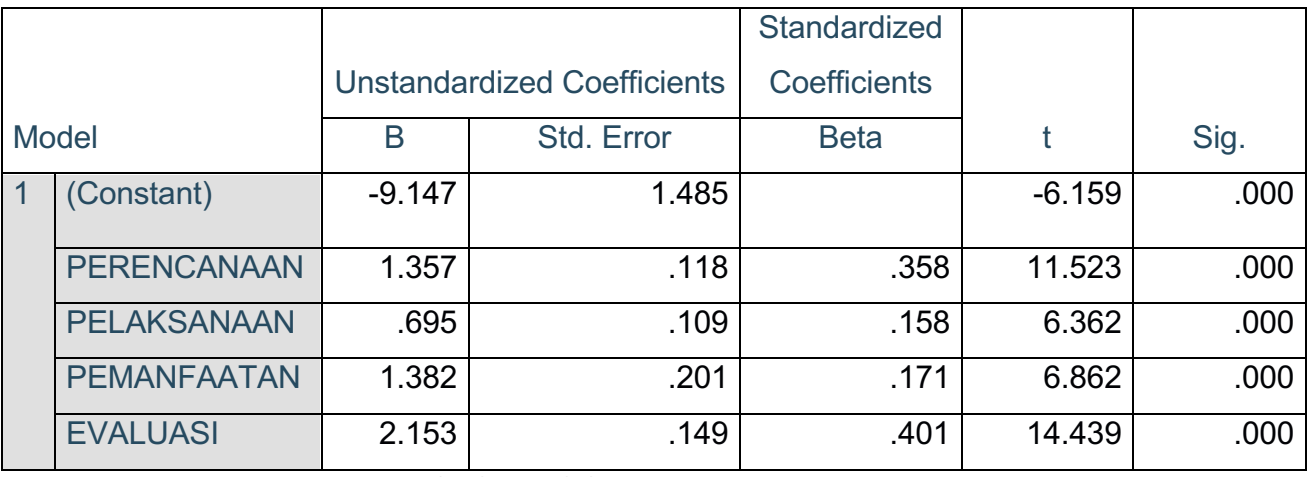

a. Dependent Variabel: REALISASI ANGGARAN

(Sumber: Hasil Pengolahan Data Menggunakan IBM SPSS Statistics 25.0, 2020) berikut:

Dari koefisien regresi yang diperoleh dapat dibentuk persamaan regresinya sebagai

$$
\begin{gathered}
Y^{\prime}=a+b 1 X 1+b 2 X 2+b 3 X 3+b 4 X 4 \\
Y^{\prime}=-9,147+1,357 X 1+0,695 X 2+1,382 X 3+2,153 X 4
\end{gathered}
$$

Dari Persamaan regresi di atas dapat dijelaskan sebagai berikut:

a. Konstanta sebesar $-9,147$ artinya realisasi anggaran dalam skala interval adalah sebesar -9,147 jika tidak ada variabel perencanaan (X1), pelaksanaan (X2), pemanfaatan (X3) dan evaluasi (X4)

b. Koefisien regresi sebesar 1,357 artinya bahwa setiap peningkatan perencanaan dalam partisipasi masyarakat sebesar satu satuan dalam skala interval akan meningkatkan realisasi anggaran di Kecamatan Bojongloa Kidul Kota Bandung 1,357 satuan.

c. Koefisien regresi sebesar 0,695 artinya bahwa setiap peningkatan pelaksanaan dalam partisipasi masyarakat sebesar satu satuan dalam skala interval akan meningkatkan realisasi anggaran di Kecamatan Bojongloa Kidul Kota Bandung 0,695 satuan.

d. Koefisien regresi sebesar 1,382 artinya bahwa setiap penurunan pemanfaatan dalam partisipasi masyrakat sebesar satu satuan dalam skala inerval akan meningkatkan realisasi anggaran di Kecamatan Bojongloa Kidul Kota Bandung 1,382 satuan.

e. Koefisien regresi sebesar 2,153 artinya bahwa setiap peningkatan evaluasi dalam partisipasi masyrakat sebesar satu satuan dalam skala inerval akan meningkatkan realisasi anggaran di Kecamatan Bojongloa Kidul Kota Bandung 2,153 satuan.

Jadi dapat disimpulkan koefisien regresi disini bertanda positif, dan dapat diartikan bahwa terjadi pengaruh positif dari perencanaan, pelaksanaan, pemanfaatan dan evaluasi terhadap realisasi anggaran di Kecamatan Bojongloa Kidul Kota Bandung pengaruh positif ini serta dapat diartikan bahwa semakin baik perencanaan, pelaksanaan, pemanfaatan dan evaluasi dalam partisipasi masyarakat realisasi anggaran di Kecamatan Bojongloa Kidul Kota Bandung juga akan meningkat, begitupun sebaliknya.

Untuk menunjukkan lebih jelas bahwa semua variabel yang penulis teliti terdapat pola hubungan, maka peneliti menyajikan grafik histogram yang dihasilkan dari output dengan menggunakan software SPSS versi 25.0 Berikut ini gambarnya: 


\section{Gambar 2}

\section{Histogram}

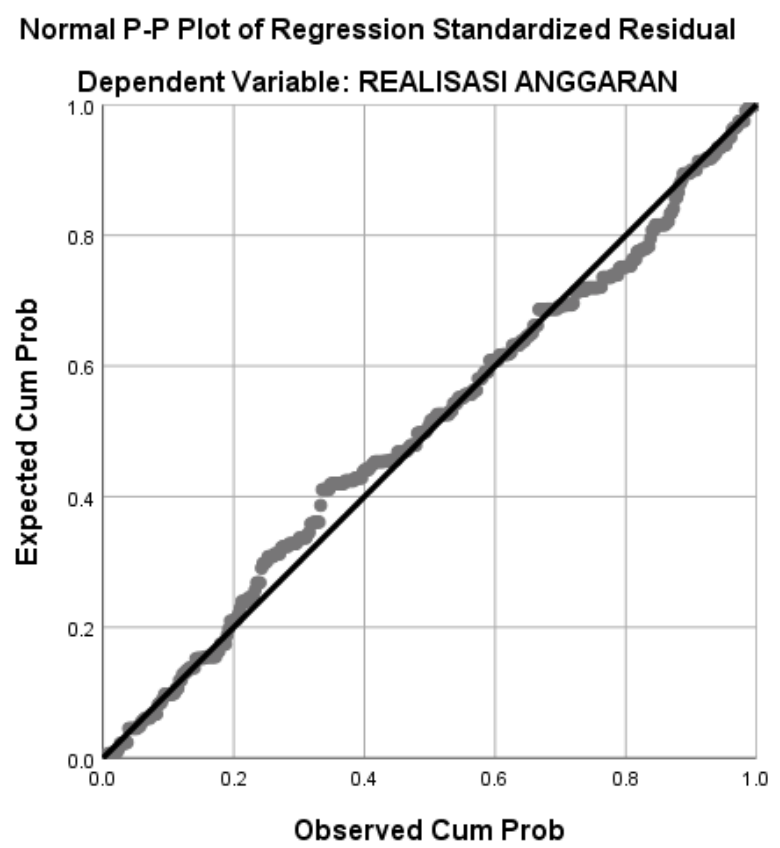

(Sumber: Hasil Pengolahan Data Menggunakan IBM SPSS Statistics 25.0, 2020)

Dari gambar di atas, terlihat gambaran hubungan antara struktur perencanaan, pelaksanaan, pemanfaatan dan evaluasi dalam partisipasi masyarakat terhadap realisasi anggaran di Kecamatan Bojongloa Kidul Kota Bandung. Dari gambar tersebut dapat diinterpretasikan bahwa terdapat kecenderungan semakin tinggi perencanaan, pelaksanaan, pemanfaatan dalam berpartisipasi maka akan semakin meningkat realisasi anggaran di Kecamatan Bojongloa Kidul Kota Bandung.

\section{Pengaruh Partisipasi Masyarakat dalam Perencanaan terhadap Realisasi Anggaran PIPPK}

Untuk mengetahui apakah dalam model regresi variabel independen perencanaan (X1) secara parsial berpengaruh signifikan terhadap variabel dependen realisasi anggaran (Y), maka dilakukan analisis berdasarkan pada hasil output analisis regresi yang tersaji dalam tabel koefisien regresi diatas.

Berdasarkan tabel koefisien hasil pengolahan data tersebut, dapat diketahui bahwa besarnya Pengaruh perencanaan terhadap realisasi anggaran. Berdasarkan tabel diperoleh $\mathrm{t}$ hitung sebesar 11,523. Tabel distribusi t dicari pada $\alpha=5 \%: 2=0,025 \%$ (uji 2 sisi) dengan derajat kebebasan df (398-4-1) $=393$. Dengan pengujian 2 sisi ( diperoleh untuk $t$ tabel sebesar 2,250. Oleh karena nilai t hitung $>t$ tabel $(11,523>2,250)$ maka Ho ditolak, artinya secara parsial ada pengaruh signifikan antara partisipasi masyarakat dalam perencanaan terhadap realisasi anggaran PIPPK di Kecamatan Bojongloa Kidul Kota Bandung. 


\section{Pengaruh Partisipasi Masyarakat dalam Pelaksanaan terhadap Realisasi Anggaran PIPPK}

Untuk mengetahui apakah dalam model regresi variabel independen pelaksanaan (X2) secara parsial berpengaruh signifikan terhadap variabel dependen realisasi anggaran (Y), maka dilakukan analisis berdasarkan pada hasil output analisis regresi yang tersaji dalam tabel koefisien regresi diatas.

Berdasarkan tabel koefisien hasil pengolahan data tersebut, dapat diketahui bahwa besarnya Pengaruh pelaksanaan terhadap realisasi anggaran. Berdasarkan tabel diperoleh $\mathrm{t}$ hitung sebesar 6,362. Tabel distribusi t dicari pada $\alpha=5 \%: 2=0,025 \%$ (uji 2 sisi) dengan derajat kebebasan df (398-4-1) $=393$. Dengan pengujian 2 sisi (signifikansi $=0,025)$ hasil diperoleh untuk $\mathrm{t}$ tabel sebesar 2,250. Oleh karena nilai $\mathrm{t}$ hitung $>\mathrm{t}$ tabel $(6,362>2,250)$ maka Ho ditolak, artinya secara parsial ada pengaruh signifikan antara partisipasi masyarakat dalam pelaksanaan terhadap realisasi anggaran PIPPK di Kecamatan Bojongloa Kidul Kota Bandung.

\section{Pengaruh Partisipasi Masyarakat dalam Pemanfaatan terhadap Realisasi Anggaran PIPPK}

Untuk mengetahui apakah dalam model regresi variabel independen pemanfaatan (X3) secara parsial berpengaruh signifikan terhadap variabel dependen realisasi anggaran (Y), maka dilakukan analisis berdasarkan pada hasil output analisis regresi yang tersaji dalam tabel koefisien regresi diatas.

Berdasarkan tabel koefisien hasil pengolahan data tersebut, dapat diketahui bahwa besarnya Pengaruh pemanfaatan terhadap realisasi anggaran. Berdasarkan tabel diperoleh thitung sebesar 6,862. Tabel distribusi t dicari pada $\alpha=5 \%: 2=0,025 \%$ (uji 2 sisi) dengan derajat kebebasan df (398-4-1) $=393$. Dengan pengujian 2 sisi (signifikansi $=0,025)$ hasil diperoleh untuk $t$ tabel sebesar 2,250. Oleh karena nilai $t$ hitung $>t$ tabel $(6,862>2,250)$ maka Ho ditolak, artinya secara parsial ada pengaruh signifikan antara partisipasi masyarakat dalam pemanfaatan terhadap realisasi anggaran PIPPK di Kecamatan Bojongloa Kidul Kota Bandung.

\section{Pengaruh Partisipasi Masyarakat dalam Evaluasi terhadap Realisasi Anggaran PIPPK}

Untuk mengetahui apakah dalam model regresi variabel independen evaluasi (X4) secara parsial berpengaruh signifikan terhadap variabel dependen realisasi anggaran (Y), maka dilakukan analisis berdasarkan pada hasil output analisis regresi yang tersaji dalam tabel koefisien regresi diatas.

Berdasarkan tabel koefisien hasil pengolahan data tersebut, dapat diketahui bahwa besarnya Pengaruh evaluasi terhadap realisasi anggaran. Berdasarkan tabel diperoleh $\mathrm{t}$ hitung sebesar 14,439. Tabel distribusi t dicari pada $\alpha=5 \%: 2=0,025 \%$ (uji 2 sisi) dengan derajat kebebasan df (398-4-1) $=393$. Dengan pengujian 2 sisi (signifikansi $=0,025)$ hasil diperoleh untuk $t$ tabel sebesar 2,250. Oleh karena nilai $t$ hitung $>t$ tabel $(14,439>2,250)$ maka Ho ditolak, artinya secara parsial ada pengaruh signifikan antara partisipasi masyarakat dalam evaluasi terhadap realisasi anggaran PIPPK di Kecamatan Bojongloa Kidul Kota Bandung. 


\section{Pengaruh Partisipasi Masyarakat dalam Perencanaan, Pelaksanaan, Pemanfaatan, dan evaluasi terhadap Realisasi Anggaran PIPPK}

Untuk mengetahui apakah variabel independen (perencanaan, pelaksanaan, pemanfaatan dan evaluasi) terhadap variabel dependen yaitu realisasi anggaran PIPPK di Kecamatan Bojongloa Kidul Kota Bandung, maka dilakukan analisis berdasarkan pada hasil analisis regresi output diketahui nilai $\mathrm{F}$ yang disajikan sebagai berikut:

\section{Tabel 3}

\section{Hasil Uji F \\ ANOVA $^{\mathrm{a}}$}

\begin{tabular}{l|r|r|r|r|r}
\multicolumn{1}{l}{ Model } & Sum of Squares & df & Mean Square & F & \multicolumn{1}{l}{ Sig. } \\
\hline 1 Regression & 29279.963 & 4 & 7319.991 & 584.952 & $.000^{\mathrm{b}}$ \\
\hline Residual & 4917.936 & 393 & 12.514 & & \\
\hline Total & 34197.899 & 397 & & & \\
\hline a. Dependent Variabel: REALISASI ANGGARAN & & & \\
b. Predictors: (Constant), EVALUASI, PEMANFAATAN, PELAKSANAAN, PERENCANAAN
\end{tabular}

(Sumber: Hasil Pengolahan Data Menggunakan IBM SPSS Statistics 25.0, 2020)

Berdasarkan tabel diatas diperoleh nilai $\mathrm{F}$ hitung untuk model regresi yang digunakan sebesar 584,952. Untuk menentukan $\mathrm{F}$ tabel Dengan menggunakan tingkat keyakinan 95\%, $\alpha=5 \%$, df1 $(\mathrm{k}=4)$, dan df2 (398-4-1) = 393, hasil diperoleh untuk $\mathrm{F}$ tabel sebesar 2,818. Nilai F hitung $>$ F tabel $(584,952>2,818)$, maka Ho ditolak. Karena F hitung $>\mathrm{F}$ tabel $(55,190>2,818)$, maka Ho ditolak, artinya ada pengaruh secara signifikan antara perencanaan, pelaksanaan, pemanfaatan dan evaluasi terhadap realisasi anggaran di Kecamatan Bojongloa Kidul Kota Bandung.

Untuk menunjukkan persentase seberapa besar pengaruh perencanaan, pelaksanaan, pemanfaatan dan evaluasi sebagai bentuk partisipasi masyarakat terhadap realisasi anggaran di Kecamatan Bojongloa Kidul Kota Bandung maka dilakukan analisis determinasi yaitu dengan cara melihat ouput model summary pada hasil analisis regresi yang disajikan pada tabel berikut:

\section{Tabel 4}

\section{Koefisien Determinasi}

\begin{tabular}{|l|r|r|r|r|r|}
\multicolumn{7}{c|}{ Model Summary } \\
\hline Model & $\mathrm{R}$ & R Square & $\begin{array}{c}\text { Adjusted R } \\
\text { Square }\end{array}$ & $\begin{array}{c}\text { Std. Error of the } \\
\text { Estimate }\end{array}$ & Durbin-Watson \\
\hline 1 & $.925^{\mathrm{a}}$ & .856 & .855 & 3.53749 & 1.964 \\
\hline
\end{tabular}

a. Predictors: (Constant), EVALUASI, PEMANFAATAN, PELAKSANAAN, PERENCANAAN

b. Dependent Variable: REALISASI ANGGARAN

(Sumber: Hasil Pengolahan Data Menggunakan IBM SPSS Statistics 25.0, 2020) 
Berdasarkan tabel di atas diperoleh angka $\mathrm{R}^{2}$ (R Square) sebesar 0,856 atau (85,6\%). Hal ini menunjukkan bahwa prosentase sumbangan pengaruh variabel independen (perencanaan, pelaksanaan, pemanfaatan dan evaluasi) terhadap variabel dependen yaitu realisasi anggaran PIPPK sebesar 85,6\% Atau variasi variabel independen yang digunakan dalam dimensi (perencanaan, pelaksanaan, pemanfaatan dan evaluasi) mampu menjelaskan sebesar 85,6\% variasi variabel dependen yaitu realisasi anggaran PIPPK. Sedangkan sisanya sebesar $14,4 \%$ dipengaruhi atau dijelaskan oleh variabel lain yang tidak diteliti oleh peneliti. Nilai koefisien determinansi yang telah dihitung sebesar 85,6\% masuk dalam kriteria pengaruh yang sangat tinggi. Sehingga dapat disimpulkan bahwa terjadi pengaruh yang sangat tinggi dari partisipasi masyarakat terhadap realisasi anggaran PIPPK di Kecamatan Bojongloa Kidul Kota Bandung. Hal ini menunjukkan partisispasi masyarakat memiliki peran yang penting dalam realisasi anggaran Program Inovasi Pembangunan dan Pemberdayaan Kewilayahan (PIPPK) di Kecamatan Bojongloa Kidul Kota Bandung

\section{Simpulan}

Berdasarkan hasil penelitian, pembahasan dan interpretasi yang telah diuraikan sebelumnya, dengan mengacu pada beberapa teori dan hasil penelitian sebelumnya, dapat ditarik kesimpulan bahwa terdapat pengaruh signifikan secara parsial dari dimensi partisipasi masyarakat terhadap realisasi anggaran PIPPK di Kecamatan Bojongloa Kidul Kota Bandung dengan masing masing nilai thitung sebesar 11,523 untuk dimensi perencanaan, nilai thitung sebesar 6,362 untuk dimensi pelaksanaan, nilai thitung sebesar 6,862 untuk dimensi pemanfaatan, nilai thitung sebesar 14,439 untuk dimensi evaluasi dimana nilai tersebut nilai $t_{\text {hitung }}>t_{\text {tabel }}$ sehingga dapat dikatakan $\mathrm{H}_{0}$ ditolak. Serta terdapat pengaruh signifikan secara simultan dari partisipasi masyarakat terhadap realisasi anggaran PIPPK di Kecamatan Bojongloa Kidul Kota Bandung dengan nilai $\mathrm{F}_{\text {hitung }}$ sebesar 584,952 yang dapat dikatakan $\mathrm{H}_{0}$ ditolak karena nilai $\mathrm{F}_{\text {hitung }}>\mathrm{F}_{\text {tabel. }}$.

\section{Referensi}

Adi, I. R. (2001). Pemberdayaan Pengembangan Masyarakat dan Intervensi Komunitas. Jakarta: Fakultas Ekonomi UI.

Agustin, M. (2015). Partisipasi Masyarakat dalam Perencanaan Pembangunan Desa Melalui Musrembang. Publika, 4(1), 1-14.

Andriani, N. M. A., Rares, J. J., \& Tampi, G. B. (2018). Partisipasi Masyarakat dalam Pembangunan di Desa Tumokong Baru Kecamatan Dumaga Utara Kabupaten Bolaang Mongondow. Publika.

Anggara, S. (2016). Administrasi Keuangan Negara (1st ed.). Bandung: CV. Pustaka Setia.

Anggara, S., Pilawati. (2019). Penyerapan Anggaran Belanja Langsung Pada Dinas Kesehatan Kabupaten Bandung. Publica: Jurnal Pemikiran Administrasi Negara. 11 (2). DOI :10.15575/jpan.v11i2.7639

Arif, B., Muchlis, \& Iskandar. (2002). Akuntansi Pemerintahan. Jakarta: Salemba Empat.

Bastian, I. (2010). Akuntansi Sektor Publik Suatu Pengantar (Edisi Ketiga). Jakarta: Erlangga.

Callahan, K. (2007). International Journal of Public Citizen Participation: Models and Methods. (December 2014), 37-41. https://doi.org/10.1080/01900690701225366 
Cohen, J. M., \& Uphoff, N. T. (1980). Participation's place in rural development: Seeking clarity through specificity. World Development, 8(3), 213-235. https://doi.org/10.1016/0305-750X(80)90011-X

Halim, A. (2017). Manajemen Keuangan Sektor Publik: Problematika Penerimaan dan Pengeluaran Pemerintah. Jakarta: Salemba Empat.

Hoerudin, C.W., Lesmana, B.E., Fatimah, W. (2018). Kinerja Belanja Daerah Dinas Penanaman Modal dan Pelayanan Terpadu Satu Pintu Kota Bandung. Publica: Jurnal Pemikiran Administrasi Negara.10 (2). DOI :10.15575/jpan.v10i2.7630

Mardiasmo. (2009). Akuntansi Sektor Publik. Yogyakarta: ANDI.

Sugiyono. (2016). Metode Penelitian Kuantitatif, Kualitatif dan R\&D. Bandung: Alfabeta.

Suyatna, U. (2011). Keuangan Negara. Bandung: Universitas Pasundan Press.

Tanjung, A. H. (2015). Akuntansi Keuangan Daerah Berbasis Akrual untuk SKPD. Bandung: Alfabeta.

Umam, K., Pratama, A.E. (2018). Dampak Sistem Pengendalian Internal Terhadap Penagihan Piutang di Kota Bandung. Publica: Jurnal Pemikiran Administrasi Negara. 10 (2). DOI :10.15575/jpan.v10i2.7626 